И С Т ОРИЯ, А Р Х Е Л Л ГИЯ, Э Т Н О Р АФ И Я

УДК 902

Н. И. Шутова

СЛОВО ОБ ИССЛЕДОВАТЕЛЕ, УЧИТЕЛЕ

И ОРГАНИЗАТОРЕ НАУКИ:

К ЮБИЛЕЮ РИММЫ ДМИТРИЕВНЫ ГОЛДИНОЙ

Статья посвящена юбилею Риммы Дмитриевны Голдиной - выдающегося археолога, доктора исторических наук, профессора кафедры истории Удмуртии, археологии и этнологии, директора научноисследовательского института истории и культуры народов Приуралья (с 1993 г.) и декана исторического факультета (1980-1991 гг.) Удмуртского государственного университета, заслуженного деятеля науки УР (1991), лауреата Государственной премии Удмуртской Республики (2001), заслуженного работника высшей школы РФ (2002), почетного гражданина Удмуртской Республики (2021), основателя и руководителя научного археологического коллектива Удмуртского государственного университета. За период работы ею опубликовано более 20 авторских и коллективных монографий и более 300 статей по древней и средневековой истории и культуре пермских народов. В статье кратко охарактеризованы основные аспекты деятельности Р. Д. Голдиной, главные научные, общественные и педагогические достижения учёного, вклад в развитие археологической мысли Камско-Вятского региона и в сокровищницу российской науки.

Ключевые слова: археология, юбилей, Р. Д. Голдина, общественная и педагогическая деятельность, научные достижения.

DOI: $10.35634 / 2224-9443-2021-15-4-663-667$

В ноябре 2021 г. отметила свой славный юбилей Римма Дмитриевна Голдина - доктор исторических наук, профессор кафедры истории Удмуртии, археологии и этнологии, директор научно-исследовательского института истории и культуры народов Приуралья (с 1993 г.) и декан исторического факультета (1980-1991 гг.) Удмуртского государственного университета (далее - УдГУ), заслуженнный деятель науки Удмуртской Республики (1991), лауреат Государственной премии Удмуртской Республики (2001), заслуженный работник высшей школы Российской Федерации (2002), почетный гражданин Удмуртской Республики (2021), основатель и руководитель научного археологического коллектива Удмуртского государственного университета. Область научных интересов Р. Д. Голдиной - история и культура финно-угорских народов Приуралья (удмуртов, коми-пермяков, коми-зырян), этногенез пермских народов. Ею опубликовано более 300 научных работ, более 20 авторских и коллективных монографий.

В рамках юбилейного очерка невозможно дать полную и детальную картину научных, общественных и педагогических достижений Р. Д. Голдиной. Поэтому здесь в краткой форме изложены авторские размышления относительно вклада Риммы Дмитриевны в развитие археологической мысли Камско-Вятского региона и в целом - в сокровищницу российской науки. Многогранные аспекты ее деятельности получили освещение в трудах коллег и единомышленников юбиляра. 
Римма Дмитриевна является основателем крупного научного коллектива, который занимается исследованием истории и культуры народов Камско-Вятского региона с древности до позднего средневековья. Начало этому положено в 1972 г., когда на историческом факультете УдГУ был организован археологический кружок и создана Камско-Вятская археологическая экспедиция (далее - КВАЭ). Подготовка кадров включала в себя чтение курсов и спецкурсов по археологии, руководство полевыми исследованиями, курсовыми и дипломными работами студентов, руководство аспирантурой и докторантурой по кафедре археологии и истории первобытного общества (УдГУ).

С 1970-х гг. на протяжении почти 50-ти лет сотрудниками КВАЭ под руководством Р. Д. Голдиной проведены фронтальные разведочные обследования бассейнов крупных и средних рек Удмуртской Республики, Кировской обл., Пермского края, отчасти - Республики Татарстан с целью выявления археологических памятников - поселений, могильников, других объектов. За период с 1973 г. и по настоящее время обследовано свыше 2000 древних памятников, изучено раскопками свыше 300 поселений и могильников разных эпох. Стационарные исследования проведены на крупных базовых археологических объектах - Аверинском, Агафоновском и Бартымском комплексах средневековых памятников, Тарасовском могильнике I-V вв. н. э., жертвенном месте Чумойтло, Верх-Саинском городище, Тураевском I и Неволинском могильниках и др.

В результате был накоплен богатый археологический материал по всем основным периодам истории края - от мезолита до XIX в. В последние десятилетия этот солидный корпус источников интенсивно вводится в научный оборот в авторских и коллективных монографиях. Новые материалы рассматриваются на широком историко-культурном фоне, с привлечением данных письменных источников, топонимии, фольклора и этнографии и широко используются для разработки хронологии, этнической и культурной атрибуции памятников, проблем развития материальной культуры, торговых и культурных связей, выполнения социальных реконструкций, характеристики особенностей домостроения.

К числу важнейших научных достижений Р. Д. Голдиной относятся систематизация и классификация полученных во время экспедиций материалов, разработка типологии и хронологии древностей Верхнего Прикамья, Вятского края, а также прилегающих территорий Нижнего и Среднего Прикамья II в. до н.э. - XIV в. н.э. Эти исследования - значительный вклад в отечественную археологическую науку; классификация Р. Д. Голдиной является базовой основой общей хронологии древностей Восточной Европы. В результате проведенных исследований очерчена не только линия развития материальной культуры отдельных археологических культур Приуралья, но и реконструирована основная схема этнической истории древних и средневековых этносов Камско-Вятского междуречья.

Еще одна важная сфера научной деятельности юбиляра - разработка проблемы этногенеза и вопросов этнической истории пермских народов. В научных трудах Р. Д. Голдиной представлен авторский взгляд на их культурную и этническую атрибутику, истоки, становление, этапы и тенденции развития пермских средневековых культур. Особо следует отметить значение монографического исследования Р. Д. Голдиной «Древняя и средневековая история удмуртского народа» (1999), посвященного проблеме «сквозного» рассмотрения основных этапов этнической истории удмуртского народа. Монография опирается на солидную базу археологических источников и подкреплена выводами из смежных научных дисциплин - истории, фольклора, этнографии, лингвистики, топонимии. Автор излагает картину истории местного населения региона от древности до Средневековья, намечает основные направления и этапы исторического пути пермских народов и других этносов края. Перед нами научное издание, в котором изложена новейшая археологическая информация об исторических процессах древности и Средневековья. В монографии в полной мере нашла отражение такая сильная исследовательская черта Р. Д. Голдиной, как умение синтезировать и обобщать объемные материалы и излагать их в виде стройной и логичной концепции. В дальнейшем многие затронутые в книге проблемы 
истории и культуры региона будут уточняться, прорабатываться, ибо в рамках одной, даже очень объемной книги, трудно охарактеризовать все аспекты истории края на протяжении такого колоссального хронологического отрезка времени. Аналогичную по широте охвата исследовательскую работу ученый готовит по Перми Великой.

Следует отметить вклад Р. Д. Голдиной в утверждение авторитета удмуртской археологии в региональном, отечественном и международном научных сообществах. Благодаря блестящим организаторским способностям Риммы Дмитриевны удавалось регулярно проводить археологические конференции, совещания, полевые симпозиумы. Ижевск стал одним из крупных археологических научных центров в стране. Среди значительных мероприятий последнего десятилетия - конференции и симпозиумы, посвященные российской археологии XX в. (Ижевск, 2000), историческому опыту толерантности народов Приуралья (Ижевск, 2002), эпохе Великого переселения народов (Ижевск, 2006), XX Уральское археологическое совещание (Ижевск, 2016).

Трудами юбиляра и коллектива единомышленников наши археологические памятники и связанные с ними исследования стали достоянием широкой научной общественности не только в России и странах бывшего Советского Союза, но и дальнего зарубежья. Длительные и плодотворные научные контакты связывали удмуртских археологов с венгерскими и австрийскими коллегами. В 1990-е гг. Р.Д. Голдина способствовала активизации обмена международными стажировками студентов и преподавателей из России, Германии, Австрии, Венгрии, Великобритании, Финляндии.

Важная сторона деятельности Р. Д. Голдиной как организатора науки - подготовка научных и преподавательских кадров для высшей школы, академических центров и музейных учреждений. Она инициировала работу диссертационного совета по защите кандидатских, а позднее и докторских диссертаций по трем специальностям: «археология», «этнография, этнология и антропология», «отечественная история». Римма Дмитриевна подготовила десятки высококвалифицированных специалистов. Среди ее учеников - три доктора (Л. Д. Макаров, О. М. Мельникова, Н. И. Шутова) и более 30 кандидатов исторических наук. В Удмуртском институте истории, языка и литературы УдмФИЦ УрО РАН ныне трудится около 20 сотрудниковисториков, получивших навыки научной работы на историческом факультете УдГУ, из них 12 чел. защитили кандидатские и два чел. (Н. П. Лигенко и Л. Н. Бехтерева) докторские диссертации в диссертационном совете под председательством Р. Д. Голдиной.

Римма Дмитриевна Голдина стала моим первым научным руководителем. Мы, студенты, слушали блестящие лекции и спецкурсы по археологии; получали навыки качественной полевой подготовки, осваивая разведочные маршруты, принимая участие в стационарных исследованиях археологических памятников разных эпох от мезолита до позднего Средневековья. Начинали работать в качестве «простых негров» (работали с лопатой, щетками и совками) и «сахемов» (как опытные студенты, которые специализировались по археологии, занимались фиксацией находок и сооружений на планы и чертежи), затем руководителей раскопов, а позднее - начальников отдельных отрядов, проводя самостоятельные раскопки. Помимо полевых исследований, Римма Дмитриевна обучала нас методам камеральной обработки полученных материалов, методике систематизации, классификации и анализа археологических коллекций, руководила подготовкой докладов на студенческие конференции, курсовых работ и дипломных сочинений. Следует подчеркнуть, что все наши научные студенческие изыскания базировались на новом оригинальном археологическом материале. Сферой моих разработок являлся керамический материал, по результатам обработки которого была подготовлена дипломная работа «Керамический комплекс погребальных памятников Верхнего Прикамья в эпоху средневековья».

Дорогая, глубокоуважаемая Римма Дмитриевна, разрешите поздравить Вас со славным юбилеем и поблагодарить за профессиональную и житейскую школу, за полученные важнейшие навыки научной и полевой работы. Крепкого здоровья, благополучия, осуществления задуманного, творческих успехов! 


\section{Основные монографии Р. Д. Голдиной}

Голдина Р. Д. Ломоватовская культура в Верхнем Прикамье. Иркутск. 1985. 280 с.

Голдина Р. Д. Древняя и средневековая история удмуртского народа. Ижевск: Изд. дом «Удм. ун-т». 1999. $464 \mathrm{c}$.

Голдина Р. Д. Тарасовский могильник I-V вв. на Средней Каме. Т. II. Ижевск, 2003. 721 с.

Голдина Р. Д. Тарасовский могильник I-V вв. на Средней Каме. Т. І. Ижевск, 2004. 319 с.

Голдина Р. Д. Неволинский могильник VII-IX вв. н. э. в Пермском Предуралье / Материалы и исследования Камско-Вятской археологической экспедиции. Т. 21. Ижевск, 2012. 472 с.

Голдина Р. Д., Берни В. А. Тураевский І могильник- уникальный памятник эпохи великого переселения народов в Среднем Прикамье (бескурганная часть) / Материалы и исследования Камско-Вятской археологической экспедиции. Т. 17. Ижевск: Изд-во «Удм. ун-т», 2010. 499 с.

Голдина Р. Д., Водолаго Н. В. Могильники неволинской культуры в Приуралье. Иркутск, 1990. 174 с.

Голдина Р. Д., Колобова Т. А., Казанцева О. А., Митряков А. Е., Шаталов В. А. Тарасовское святилище раннего железного века в Среднем Прикамье / Материалы и исследования Камско-Вятской археологической экспедиции. Т. 26. Ижевск, 2013. 184 с.

Голдина Р. Д., Лещзинская Н. А., Черных Е. М., Берни В. А. Наследие народов Прикамья. Древности Прикамья из собраний Удмуртского государственного университета. Ижевск. 2007, 2012. 196 с.

Голдина Р. Д., Пастушенко И. Ю., Перевозчикова С. А., Черных Е. М., Голдина Е. В., Перевошиков С. Е. Городище Лобач и его окрестности в эпоху средневековья / Материалы и исследования Камско-Вятской археологической экспедиции. Т. 23. Ижевск, 2012. 264 с.

Голдина Р. Д., Пастушенко И. Ю., Черных Е. М. Бартымский комплекс памятников эпохи средневековья в Сылвенском поречье // Материалы и исследования Камско-Вятской археологической экспедиции. Т. 13. Ижевск, Пермь, 2011. 340 с.

Древности Прикамья эпохи железа (VI в. до н. э. - XV в. н. э.): хронологическая атрибуция / Материалы и исследования Камско-Вятской археологической экспедиции. Т. 25. Ижевск: Изд-во «Удм. ун-т», 2012. 544 с.

О ней:

Чернобаев A. А. Историки России: Кто есть кто в изучении отечественной истории: Биобиблиогр. слов. Саратов: Изд. центр Саратов. гос. соц.-экон. ун-та: Летопись, 2000. С. 116-117.

Голдина Римма Дмитриевна // Удмуртская Республика: Энциклопедия / Гл. ред. В. В. Туганаев. Ижевск: Изд-во «Удмуртия», 2000. С. 279.

Голдина Римма Дмитриевна: к 60-летию со дня рождения: биобиблиогр. указ. / Отв. ред. Л. П. Бесклинская, сост. Р. Р. Боброва. Ижевск, 2001. 38 с. (Биобиблиография учёных УдГУ).

Голдина Римма Дмитриевна // Археологи Волго-Уральского региона: справочник / Отв. ред. С. В. Кузьминых; сост.: Г. Т. Обыденнова, И. А. Шутелева, Н. Б. Щербаков. Уфа: Гилем, 2002. С. 22.

Кананин B. A. Голдина Римма Дмитриевна // Историки Урала XVIII-XX вв. Екатеринбург: УрО РАН, 2003. С. 85-86.

Голдина Римма Дмитриевна // Удмуртская Республика: Энциклопедия / Гл. ред. В. В. Туганаев. Ижевск: Удмуртия, 2008. С. 281.

Мельничук A. Ф., Черных E. М. К юбилею Риммы Дмитриевны Голдиной // Российская археология. 2012. № 4. C. 183-184.

Голдина Римма Дмитриевна // Удмуртская Республика: Культура и искусство = Удмурт Элькун: Лулчеберет но устолык: энциклопедия / Гл. ред. А. Е. Загребин. Ижевск, 2014. С. 136-137.

Кананин B. А. Голдина Римма Дмитриевна // Камско-Вятской археологической экспедиции Удмуртского государственного университета - 40 лет / Сост., науч. ред. Н. Ф. Широбокова. Ижевск, 2015. C. $98-102$.

Богачев А. В. Наука без «посредников» (к юбилею Риммы Дмитриевны Голдиной) // Вестник Удмуртского университета. Серия: История и филология. 2021. Т. 31. № 4. С. 678-682.

Bыборнов A. A. Роль диссертационного совета Удмуртского государственного совета в подготовке специалистов по каменному веку Волго-Камья // Вестник Удмуртского университета. Серия: История и филология. 2021. Т. 31. № 4. С. 694-699. 
Лещинская Н. А., Мельникова О. М., Черных Е. М. Археология как призвание: к юбилею археолога Риммы Дмитриевны Голдиной // Вестник Удмуртского университета. Серия: История и филология. 2021. T. 31. № 4. С. 671-677.

Савельева Э. А. Пермский мир в древности и средневековье в работах Р. Д. Голдиной // Вестник Удмуртского университета. Серия: История и филология. 2021. Т. 31. № 4. С. 683-693.

Поступила в редакцию 12.11.2021

Шутова Надежда Ивановна, доктор исторических наук, ведущий научный сотрудник, Удмуртский институт истории, языка и литературы, УдмФИЦ УрО РАН, 426004, Россия, г. Ижевск, ул. Ломоносова, 4, e-mail: nad_shutova@mail.ru

\title{
N. I. Shutova \\ THE WORD ABOUT THE RESEARCHER, TEACHER AND ORGANIZER OF SCIENCE: TO THE ANNIVERSARY OF RIMMA DMITRIEVNA GOLDINA
}

\author{
DOI: $10.35634 / 2224-9443-2021-15-4-663-667$
}

The article is devoted to the anniversary of Rimma Dmitrievna Goldina. Dr. R. D. Goldina is the prominent archeologist and Doctor of Historical Sciences, Professor of the Department of the Udmurt History, Archeology and Ethnology, Director of the Research Institute of the Urals Peoples History and Culture (since 1993), and Dean of the Faculty of History (1980-1991) in the Udmurt State University, "Honored Scientist of the Udmurt Republic" (1991), "Laureate of the State Prize of the Udmurt Republic" (2001), "Honored Worker of the Higher Education of the Russian Federation" (2002), Honorary Citizen of the Udmurt Republic (2021), the founder and head/leader of the archaeological collective of the Udmurt State University. During the period of the scientific research Dr. R.D. Goldina published more than twenty single author and multi-author monographs, as well as more than three hundred articles on the ancient and medieval history and culture of the Permian peoples. Here is the main aspects of the life and work of R. D. Goldina, and her public and academic activity describes in a brief form. Through her scientific achievements and organizational skills, she made the significant / important contribution to the development of archaeological thought in the Kama-Vyatka region and to the treasury of Russian science.

Key words: Archeology, Anniversary, R. D. Goldina, Public and Academic Activities, Scientific Achievements.

Citation: Yearbook of Finno-Ugric Studies, 2021, vol. 15, issue 4, pp. 663-667. In Russian.

Received 12.11.2021

Shutova Nadezhda Ivanovna,

Doctor of Historical Sciences, Leading Research Associate, Udmurt Institute of History, Language and Literature, Udmurt Federal Research Center of the Ural Branch, Russian Academy of Sciences 4, Lomonosova st., Izhevsk, 426004, Russian Federation, e-mail:nad_shutova@mail.ru 